\title{
PERFORMANCE AND PRELECTION IN THE EARLY PRINTED EDITIONS OF CELESTINA
}

\author{
Isidro J. Rivera \\ University of Kansas
}

For "Papi"

"... all of us, as we read, use the literary work to symbolize and finally replicate ourselves. We work out through the text our own characteristic pattern of desire and adaptation. We interact with the work, making it part of our own psychic economy and making ourselves part of the literary work - as we interpret it."

Norman Holland, "Unity" 124.

\begin{abstract}
Although many scholars are reluctant to concede the theatricality of Celestina, recent approaches to this late fifteenth-century text have confirmed the need to reassess its performative aspects. ${ }^{1}$ Emilio de Miguel's recent monograph has recently outlined in a persuasive manner the inherent theatricality of Celestina. ${ }^{2}$ Other investigators have also
\end{abstract}

\footnotetext{
${ }^{1}$ M. R. Lida de Malkiel's study remains the most thorough examination of the dramatic sources of Rojas's work (see especially pages 27-265). Stern (190-194) and Russell (53-55) provide excellent overviews of the arguments concerning the possibility of dramatic representation of Celestina. Gilman's observations (194) conceming the work's originality and its reliance on dialogue serve as a starting point for recent critical discussions of this topic.

${ }^{2}$ Emilio de Miguel concludes that Rojas conceived of Celestina as a theatrical work: "La Celestina es obra transmitida en su época por el sistema de lectura pública, pero concebida desde aspiracicnes radicalmente teatrales (...) el autor
} 
begun to reconsider the interactions of audience, traditions, and new cultural practices. ${ }^{3}$ This approach to Rojas's text has emphasized the need to examine those cultural practices which shaped and defined the representation of Celestina during the early modern period.

Studies by Corfis and Maurizi have called for a new understanding of the performative aspects of the Celestina text. Corfis's study, in particular, has identified a manuscript document from the mid-sixteenth-century which testifies to the existence in early modern Castile of readers and listeners attentive to Celestina's "dramatic context" (45). According to Corfis, this early modern public engaged in the performance of the work: "Readers of Celestina are expected to read the dialogue as they would read any dramatic work: to participate in working out the action the author wants to reveal" (44). Corfis concludes with an affirmation that Celestina was a "performance text" intended to be read aloud within a group setting (45). This orientation provides an important starting point for understanding some of the dynamics shaping the prelection and representation of Rojas's text. ${ }^{4}$ Performance in this context is tied to a collective process by which a prelector oralized a text for the benefit of an audiate accustomed to aural literature. ${ }^{5}$

In this essay I will suggest that any discussion of performance and prelection in Celestina needs to be grounded in a careful investigation of the material aspects of the early imprints of Rojas's work. Because the impact of print culture on the mode and manner of the performance of Celestina has received relatively little attention, I will examine some of the social and cultural circumstances which conditioned the reception of the text during the early modern period and will endeavor to make the concept of performance and prelection more precise.

escribe un texto dotado de todos los resortes y condicionamientos de representabilidad" (144).

${ }^{3}$ See the studies by Corfis, Lawrance, Maurizi, Rivera, and Snow.

${ }^{4}$ According to Coleman, "prelection" is equivalent to "public reading destined to one or more listeners" (35). I employ the term "prelector" to designate the agent who reads a written text aloud to one or more listeners. Coleman's study of public reading in late medieval Europe prc rides an essential introduction to the topic of private and public reading in this period.

5 The term 'audiate' refers to "experienced and able hearers who are accustomed both to the matter and manner of traditional oral and aural literature" (Coleman 228). 
Since early writings on Celestina provide important testimony for the performative aspects of Rojas's text (Corfis 33-45), many of the early printed texts of Celestina, in a similar fashion, contain descriptions of the sociohistorical circumstances affecting the prelection of Rojas's text. Comments found in the Prólogo confirm that the early modern audience of Celestina gathered in groups to hear the text read aloud and discussed: "Assí que quando diez personas se juntaren a oír esta comedia, en quien quepa esta diferencia de condiciones, como suele acaecer, ¿quién negará que aya contienda en cosa que de tantas maneras se entienda?" (P.24). ${ }^{6}$ The practice of assembling in small groups to listen to recitation of the "comedia" by designated readers fosters an environment of "sociability" which would produce, according to Chartier ("Texts" 158-159), an exchange of insights on the text. In group read-aloud situations, each member of the audiate would potentially share in the negotiation, commentary, and understanding of the text. Such a group dynamic would in turn give access to a whole range of emotions and responses to the text, making the experience materially different from that of reading a book by oneself?

A second important document related to performative aspects of Celestina is found in verses appended to the early editions. The octavas by Alonso de Proaza, corrector of the text and professor of Rhetoric at the University of Valencia, ${ }^{8}$ describe "el modo que se ha de tener leyendo esta comedia":

Si amas y quieres a mucha atención, leyendo a Calisto mover los oyentes, cumple que sepas hablar entre dientes, a vezes con gozo, esperança y passión, a vezes airado con gran turbación.

Finge leyendo mil artes y modos, pregunta y responde por boca de todos,

${ }^{6}$ All references to Celestina, except where noted, are taken from the edition by Marciales. I utilize his section divisions, indicating in parentheses the location of the reference.

7 Susan Noakes in her study of medieval reading habits describes the experience of community reading as follows: "In such circumstances the interpretation of the text developed by any single reader or listener was the product not of her or his understanding of the text alone but of a combination of questions and insights supplied by others" (27).

${ }^{8}$ Concerning Proaza, consult McPheeters. 
llorando y rïendo en tiempo y sazón. (AP.4)

These recommendations, which first appear in print in a Toledo edition of the 16-act Comedia published circa 1500 by Pedro Hagenbach, provide textual evidence that reading not only entailed oral delivery, but also required expressive portrayal of each ch:aracter, utilizing a wide range of techniques that would move the audiate to enhanced enjoyment of the text. This type of representation reflects well-established Isidorian precepts for dramatic performance (Jones 43-44). It is also likely that this mode of performance flourished as part of academic practices at various universities, and in particular at the University in Salamanca, during the period corresponding to Rojas's writing of the Comedia (Lawrance 84-85). The links between Rojas's work and academic representation of Humanist comedies have led Lacarra and Chartier to conclude that Celestina was intended to be performed before a small audience. ${ }^{9}$ It is important to conceptualize the relationship between prelector and audiate as one which promotes the construction of a "visual dimension, the virtual world of the Tragicomedia" (Stern 199). Skilled prelectors would create voices, vary intonations, and communicate situations more vividly than in a private reading. This socio-historic aspect of Celestina aligns Rojas's text much more with performative, rather than with novelistic discourse.

Both Prólogo and octavas are s.tested quite early in the textual history of Celestina. The first extant witness for the Prólogo appears in a Toledo edition of the Tragicomedia of '1502'[1510] attributed to the workshop of Hagenbach. The octavas with their appearance in the Comedia (Toledo: Hagenbach, 1500) predate the Prólogo by several years. Both elements are missing from the only extant copy of the princeps of the Comedia (Burgos: Fadrique de Basilea, 1499?). These textual materials, however, constitute "culture-texts" which reflect the particular social and historical circumstances associated with the vocalized performance of Celestina and which document the historical and cultural practices

9 Chartier has observed that Celestina "was written for a vocalized and dramatized reading, but nonetheless a reading for solo voice intended for a small and select audience" ("Leisure" 104). In a similar manner, Lacarra has commented that "la obra era un drama leído que se representaba ante un pequeño grupo, probablemente de amigos, como parece se 'iacía con las comedias humanísticas coetáneas" (38). 
shaping the representation of Celestina. ${ }^{10}$ The mode promoted by Proaza in particular encourages the performance and prelection of Rojas's work before an audience. Maurizi has observed that these verses situate the performance of the text within a distinctly theatrical environment: "El lector que obedece los preceptos de Proaza establece un nuevo vínculo con el público. Nuevo emisor de un mensaje ahora oralizado, convierte a sus oyentes en espectadores" (154). In order to communicate the fictional world of the text, the prelector would need to employ a full range of expressive strategies which would convey to the listeners the complex situations and emotions of Rojas's work. By embracing the recommendations of Proaza, early prelectors of Celestina would generate a dramatic and spectacular version of Rojas's text.

The paratext of the early imprints of Celestina provides additional evidence for the existence of a performance regime for Rojas's text. Commencing with the 1499 ? imprint, the early editions of the Comedia and the Tragicomedia offer a visual program consisting of woodcuts, ornate initials, and other decorative devices which complement the verbal text (Berndt Kelley; Rivera; Snow, "La iconografia"). Of the twenty-nine editions inventoried by Marciales in his "Resumen de las ediciones priores" (1:9), twenty-three, roughly 80 per cent of the editions, contain such visual programs. ${ }^{11}$ These illustrated editions, spanning the period from 1499 to 1540, testify to the practices of publishers of Rojas's text during the first century after the introduction of printed books. While the inclusion of pictorial elements reflects a strategy destined to make the printed book more marketable, the number of illustrated editions suggests another possibility. Early publishers were extremely attentive to the needs of their readership as Chartier has observed (The Order of Books 13). Snow, for example, reminds us of the efforts of publishers to create user-friendly texts: "The printers of this period did much to identify for the reader the types that populate Rojas's world" ("The Iconography" 25).

${ }^{10}$ Paul Davis (4-13) adopts the term 'culture-text' to describe the dynamic interaction of texts, readers, and "the context that produced them" (13). Davis, moreover, argues that a 'culture-text' represents "the sum implicit in its many versions or concretizations" (242). The early editions of the Tragicomedia provide insight into the cultural dynamics of Rojas's text and form a corpus of 'culturetexts' which attest to the practices of readers during the early modern period.

11 Of the 29 editions listed by Marciales, 3 editions lack any sort of illustrations: Roma 1506, Milán 1516, Amteres 1539. Three more are listed as containing only one illustration, most likely a title page: Toledo 1500 , Sevilla 1501, Zaragoza 1507 (?). The early foreign translations of Celestina also incorporated pictorial programs as Snow ("The Iconography") has shown. 
Given the complex, dialogic nature of the text, it was incumbent on the publishers to employ paratextual strategies which made the text accessible to readers, listeners, and prelectors alike.

The woodcut illustrations occupy a privileged position in the hierarchy of the printed page. Typically they were the first elements noticed by the owner of the text and in addition commanded the attention of those handling the text. At the same time, each woodcut offered a mimetic space which invited contemplation of setting, dress, and activities. The visual program of these editions resulted in a series of protocols which determined how the text was to be understood. As a result, the images found in the early imprints of Celestina transformed readers and prelectors into spectators whose agency mediated the verbal and visual codes of the text.

Before continuing, it is important to comment on the relationship between words and images during the early years of print. One would expect text and picture in such close proximity to constitute two mutually incompatible codes vying for the readers' attentions. With the advent of print, these two codes operated somewhat differently. According to Camille, with the introduction of print pictorial and verbal elements were processed together and not separately because "the image has the same black and white structure as the word..." (281-283). As a result of this new practice, readers were invited to process images and words as one integrated unit on the page. In the case of the early printed editions of Celestina, the integration of visual and verbal elements creates a register from which the reading public could borrow as it worked through the text as a whole. With the addition of woodcuts, the readers/prelectors acquire a repertoire of images which supplement the fictional and affective context of the accompanying verbal text.

It is instructive to examine how the confluence of visual and verbal codes in the early imprints of Celestina within the paratext supports the performative aspects of Rojas's text. To illustrate, I have selected a representative woodcut (Figure 1), dating from an edition of the Tragicomedia published by Juan Batista Pedrezano in 1523. This particular imprint attests to some of the visual strategies utilized by early publishers of Celestina to illustrate Rojas's text. Its pictorial program, inspired by a woodcut series found in early editions produced by the Seville workshop of Polono/Cromberger, employs several design features 
con oio oe mi cafa:tup effotro:no be bozeo no allegue la be zinidadino me bagape falir oe fero:no querape que falgan.

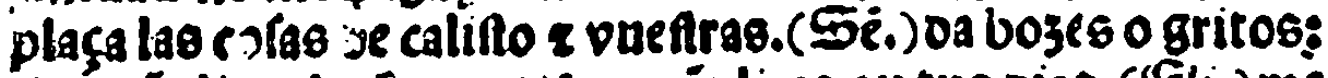
q tu cüpliras lo qu pmetifte:o cüpliras op tus oias. (EEli.)me Ie poz olos el épada. Een lo parmeno:té lo no la make effe oefúariado. (Rele.). jufficis jufticia : leñozes pezinos : juftí cia que mesmatan en mi calseftos rufianes. (5em.) rufiantes - que ? épera vona bechizera : que vo te bare yr al inferno cors cartag. (Leleftina.) ap que me ba muerto:ap ap:pfeftion conferfion. (IDarmeno.) oale oale acabala pues començafte q́ nos fentisfan:muera muera: oelos enemigos los menos.

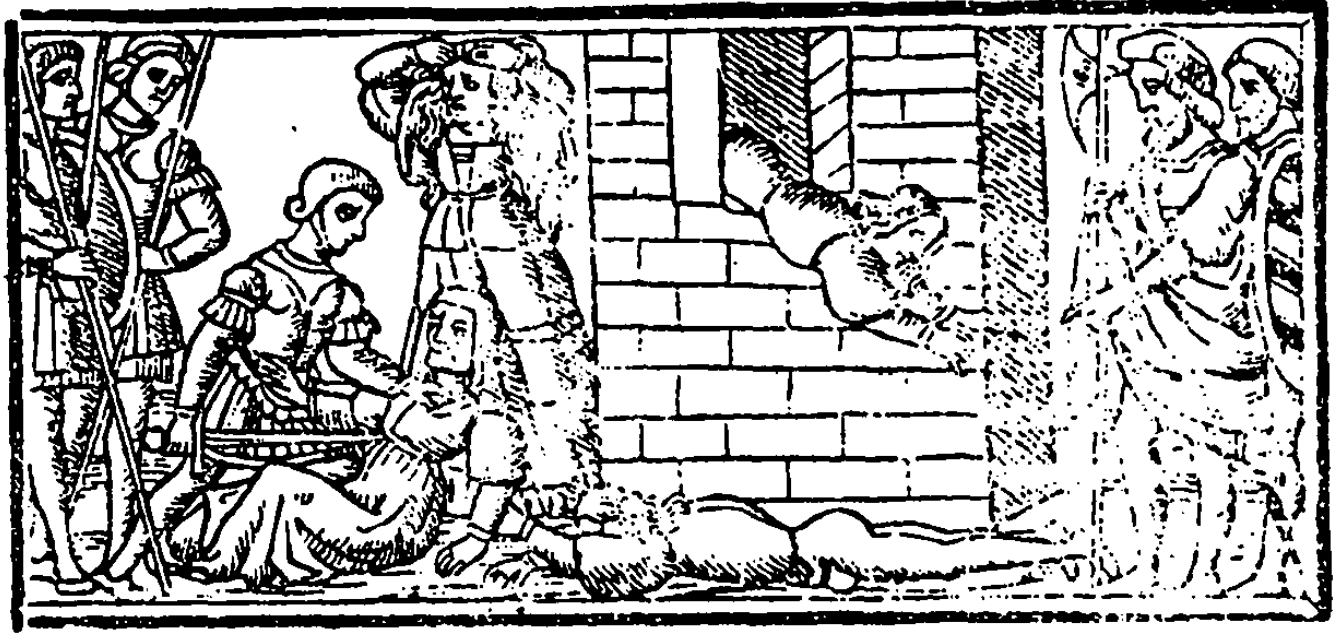

(Ee) conferfion.(Eli.) o crueles enemigos en mal poder 08 veare : 7 para quien touifles manos muerta es mi madre a mi bien rodo. ( $5 \mathrm{em}$ ) bupe bupe parmeno : que carga mucba gente. Buarte gaarte que vien el alguajif. (Dar.) ay pecadoz de mi : que no ap poz oo noo pulnos:que efta tol mada la puerta. (Fempzonio.) faltemos oeftas ventanise: no muramoo en poder or jufticia. (Barmeno.) Salta que zo trafti vop.

\section{(13arumento oel terjeno aucto.}

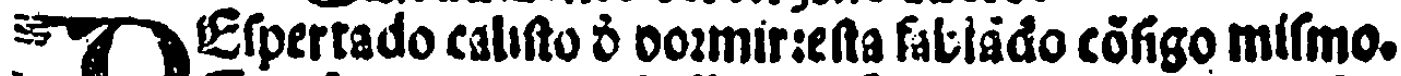
Dendes vin poco efta llamando a triftan $z$ otros fus eriados. Eọna a oostinir calufio. Done fe trîta ala puerta:vie

\section{FIGURE 1}

Murder of Celestina and escape of Sempronio and Pármeno, Tragicomedia de Calisto y Melibea, Sevilla [Venice?], Juan Batista Pedrezano, 1523 (New York, The Hispanic Society of America, sig. I $\left.4^{v}\left[=f .68^{v}\right]\right)$. Courtesy of The Hispanic Society of America. 
which support the performative goals of the text. ${ }^{12}$ This particular woodcut (Figure 1) occurs near the conclusion of auto 12 and offers a pictorial narrative of the climactic moments of that auto: the murder of Celestina with the subsequent escape of Pármeno and Sempronio through a window. The cut, occupying the full-width of the middle of folio $68^{v}$ (= Sig. I $\left.4^{v}\right)$, creates an important mimetic space for the readers / prelectors. The spatial organization of the illustration invites us to see "the particular arrangement of chronological successions and causal links in the narrative" (Davis, Masking 239). The two-panel structure of the cut imposes a sequence which approximates the chronology of events narrated in the verbal text just above and below the cut. The text immediately above the cut reads:

(ELI.) Mete por dio el espada. Ten lo parmeno ten lo no la mate esse desvariado. (Cele.) justicia justicia: señores vezinos: justicia que me matan en mi casa estos rufianes. (Sem.) rufianes o que espera doña hechizera que yo te hare yr al infierno con cartas. (Celestina.) ay que me ha muerto ay confession confession. (Parmeno.) dale dale, acaba pues comencaste que nos sentiran: muera muera: delos enemigos los menos.

Below the woodcut, the text continues with the following:

(Ce.) confession. (Eli.) o crueles enemigos en mal poder os veays: et para quien touistes manos muerta es mi madre e mi bien todo. (Sem.) huye, huye parmeno: que carga mucha gente. Guarte guarte que viene el alguazil. (Par.) ay pecador de mi: que mo ay por do nos vamos: que esta tomada la puerta. (Sempronio). Saltemos destas ventanas: no muramos en poder de justicia. (Parmeno.) Salta que yo trasti voy. (Folio $\left.68^{v}\right)^{13}$

${ }^{12}$ This image resembles a woodcut utilized by the Crombergers in their imprints of the Tragicomedia. In the catalogue compiled by Griffin, this woodcut bears the number WC: 124 . For an overview of this family of imprints, see comments by Marciales 1: 248-249.

${ }^{13}$ Quotations from the Tragicomedia published at Sevilla? [Venice] by Juan Batista Pedrezano in 1523 are taken from an exemplar located in the Hispanic Society of America, New York. The transcription respects the orthography of that imprint and does not add accents or modern punctuation. I expand abbreviations silently when necessary. 
At first glance the organization of the page seems to disrupt the flow of the verbal text. Given the practices at work in early print culture, as noted earlier, the verbal and visual codes would be processed as one since the black and white aesthetic of the printed page neutralizes the split between pictorial and verbal codes (Camille 281-283). The mise-enlivre thus invites the contemporary audience of Rojas's text to engage in a series of movements, from dialogue to woodcut and back to dialogue. The interplay of these codes invites the reader to reconstruct the fictional text and thus to participate in what Proaza has characterized as "Finge leyendo," the transformation of discourse into spectacle.

Within the context of oralized reading of Celestina, the visual code is likely to have had a significant impact on how the prelector realized the text since the woodcut images transfer the diegetical nature of the dialogue onto a mimetic plane and, in so doing, foreground specific dramatic actions. The left panel (fig. 1), depicts the violent assault on Celestina. This action develops through a skillful juxtaposition of actors within the scene. A prostrate Celestina victimized by Sempronio dominates the center of the panel. The positioning of the figure of Sempronio with sword in hand concretizes the brutality already referred to in the dialogue. Similarly the image of Elisa, who stands to the right of the central action in the panel, distraught and with arms upraised, intensifies the savagery of Sempronio's attack. Elisa's gestures within the cut especially strengthen the emotional register suggested in the verbal text. The pictorial representation, which confirms the horror of the scene, is the primary vehicle for the vocal dramatization of the gruesome assassination of Celestina. Similarly, the disposition of the various characters reinforces aspects of the accompanying text and invites the prelector (and reader) to visualize the atrocities committed by the menservants. The skilled prelector would easily adjust his/her execution of the text in accordance with the mimetic codes communicated by the mise-en-livre, resulting in a performance consistent with the recommendations of Proaza.

The right-hand panel of fig. 1 is a rendering of the escape of the two servants; it follows a similar protocol for combining word and image. The panel takes its cue from various references to escape in the dialogue. The verbs 'huye, huye,' 'saltemos,' and 'salta' invoke the actions escape which the woodcut condenses into a single, dynamic image. The disposition of the figures dramatizes effectively the flight of the two assassins and their subsequent capture by the authorities. The panel depicts Pármeno in motion while Sempronio, who has already exited, lies below the window. The juxtaposition of movement and static action encourages the prelectors (as well as the silent reader) to visualize 
the action and to generate from the confluence of visual and linguistic elements a series of "chronological successions and causal links" (Davis, Masking 239). At the same time this operation casts the prelector (as well as the solitary reader) as participant/spectator in a theatricalization of the text. In this example, the pictorial program provides a series of protocols for uniting acoustic and visual registers in order better to experience Celestina. The practice of juxtaposing pictorial and verbal elements affects how the prelector presents the text to his audiate. Within the context of early printed texts, pictorial and verbal elements, story and images, were conceived as interrelated, dependent, and tightly interwoven within the fabric of the printed book. The text and paratext of Celestina offer the prelectors cues for expressive delivery, thus enhancing the experience of the text and its fictional universe.

Some early imprints of Celestina utilize other methods of illustration to achieve a similar goal. Instead of narrative woodcuts, publishers frequently employ composite images (factotum blocks) which contained individual woodblocks of people, animals, or scenery. This method of illustration afforded publishers greater versatility without the expense of crafting a set of unalterable woodcuts for each book produced by their presses. As Snow points out, copies of these blocks were frequently shared by publishers ("The Iconography" 25). ${ }^{14}$ Publishers would routinely select individual blocks from their stock and arrange them in a lateral strip to form a composite image according to the requirements of a particular book (Griffin 198). This method of illustration allowed publishers to produce a visually appealing product without increasing the cost of production. Owing to the realities of book production, publishers employed this type of illustration so as to compete more profitably and successfully within the marketplace. ${ }^{15}$

14 The acquisition of blocks from other printers and the reuse of blocks from previous publications were common practices in the printing shops of early modern Europe. See the comments by Hirsh (49) and Tedeschi (45-46).

${ }^{15}$ Goldschmidt reminds us: "Printing was from the start a commercial enterprise, and however often printers and publishers have lost their money in the past five centuries, there has never beell a book that went to press unless the printer rightly or wrongly believed he could make a profit by printing it" (13). Griffin makes a similar observation: "The capitalists and merchants who backed the presses and knew how to distribute manufactured goods along the established trade routes treated books just as they did other merchandise, as a commodity to be produced and sold in order to realize a profit" (2). 
De sclenina:la qua i mucbole olze oclos fecbos a cenormiention: iu madre:indus lendo le aamoz z concordia oe fempronio.

4 Calito. Delibea. Damerio. Sempionto. Eeleftina. Elicia - Erito .
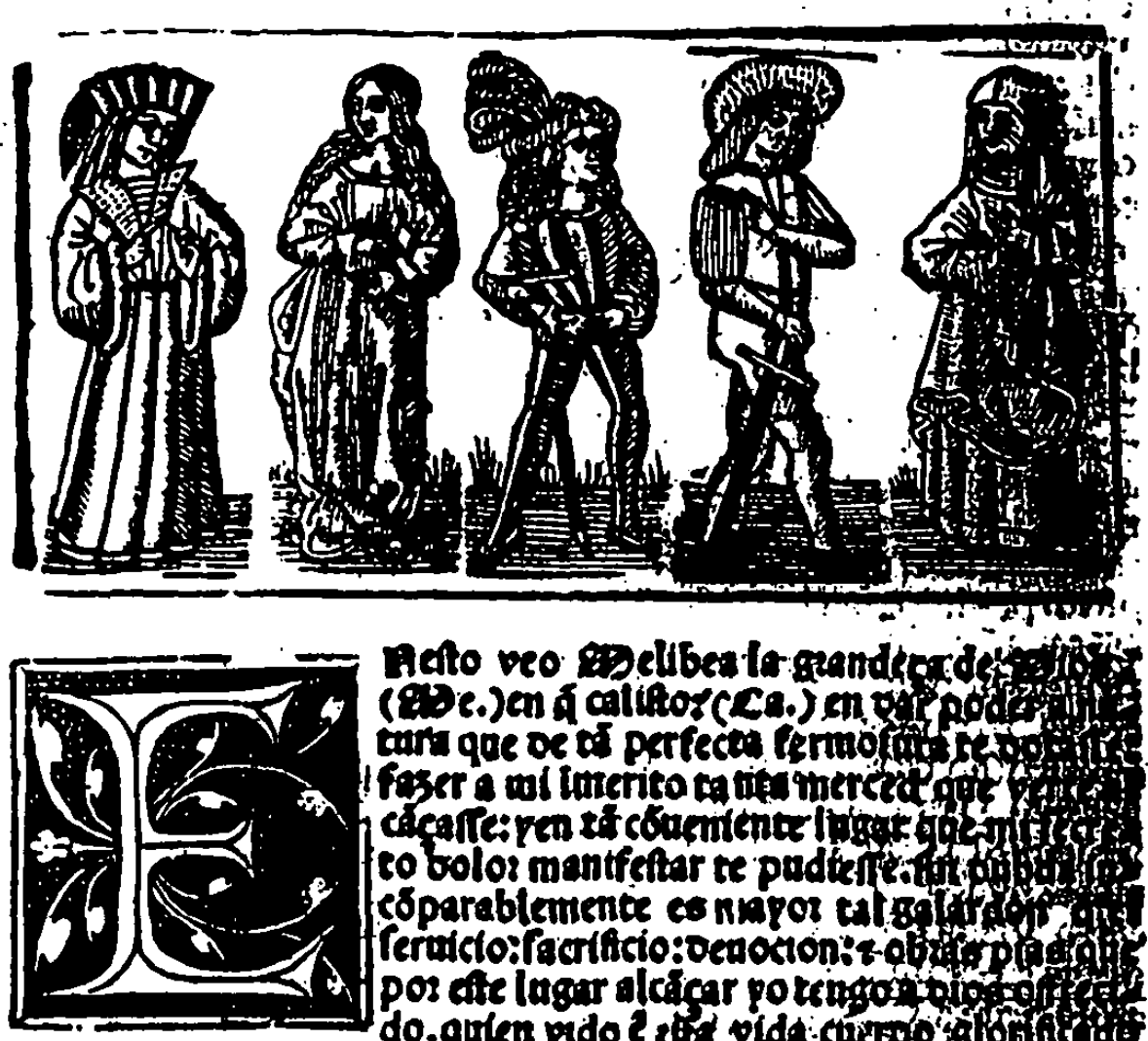

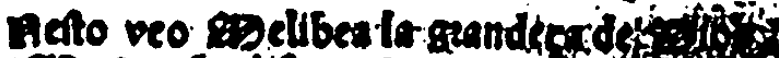

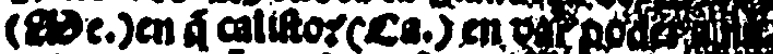

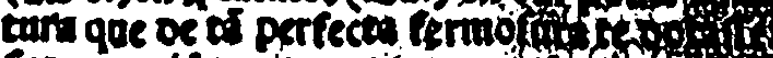
foser a wi incrito tatitemercet ony

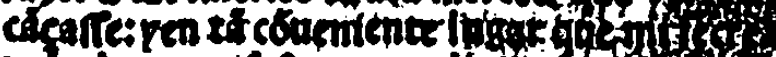
co bolor mantfeftar te pudter to or of esparablementie connapor tatgolf

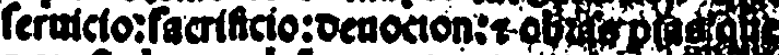

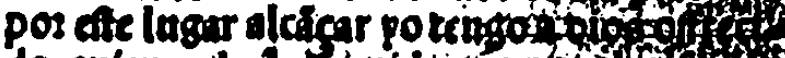

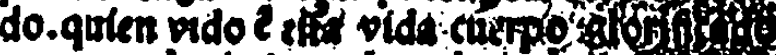
- e nigun bembre como agora el míospot ciertolos glortg of th

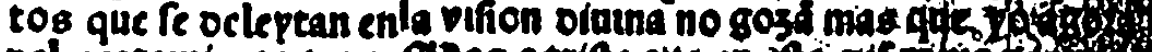
nel acatamiento tupo. Q los puramente fe glozfican fin temoz oe caer oe sal breth ca: 7 ro mirmo me alegro con recelo oel cequipo roimeto of $^{2}$ in

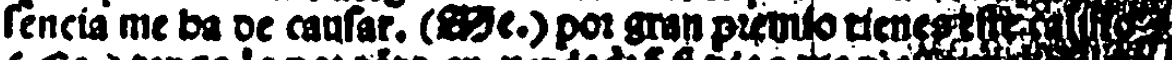

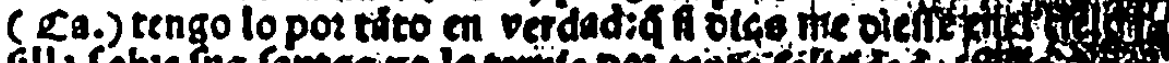

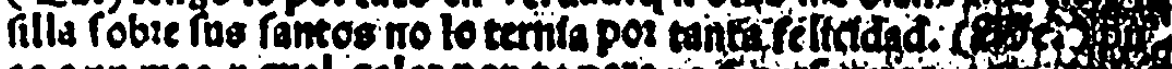

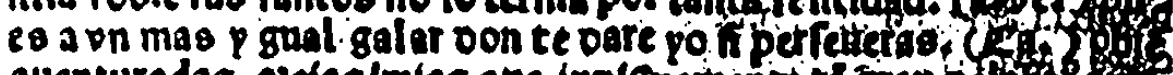

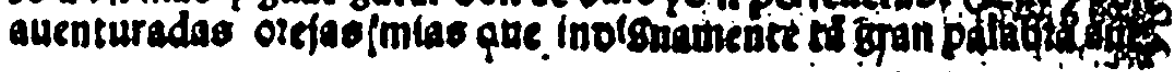

FIGURE 2

"Síguese la Comedia" and the "Argumento del primer aucto" (left); Factotum Blocks for Auto 1 (right), Tragicomedia de Calisto y Melibea, Salamanca [Rome], Antonio de Blado [Antonio de Salamanca], 1502 [c. 1520] (New York, The Hispanic Society of America, sig. A $5^{r}[=$ f. 57). Courtesy of The Hispanic Society of America. 
In the case of Celestina, the factotum blocks provide a second visual strategy that complements the performative nature of the text. To make clear the functioning of these blocks in early imprints of Celestina, this example from an edition of the Tragicomedia published at Rome by Antonio de Blado [Antonio de Salamanca] in 1520 will serve. The edition contains a total of 24 woodcut illustrations which can be broken down into three distinct hierarchies: an illustrated title page, seventeen page-width composite strips containing factotum figures with four to five figures to a strip, and 6 page-width narrative blocks employed to render more vividly selected episodes from the text. The factotum blocks form a dominant pictorial code which influences the reading and prelection of Rojas's text. Our example from the Rome, 1520 is on folio $5^{x}$ (=Sig. A $5^{r}$ ) (Figure 2). The selected factotum block occupies the full width of the page and immediately follows the argumento of the first auto. Excluding the illustrated title page, this cut is the first pictorial element experienced by the reader and prelector. Its position relative to the text initiates a series of movements, from text to woodcut and back to text which invites the spectator to harmonize words and images.

The composite block, modeled on similar ones originating in the workshop of Polono/Cromberger, depicts a series of characters: from left to right, an elegantly dressed nobleman, a maiden, two young men, and an old woman. ${ }^{16}$ The listing of names above the block links the illustrations to the text. Attentive readers and prelectors would logically make the connection with the accompanying text especially since it has just made mention of some of these characters. In the case of Calisto, the argumento general describes him as "de noble linage, de claro ingenio, de gentil disposición". Similarly, Melibea is "muger moça, muy generosa, de alta y serenissima sangre". The block enables readers or prelectors to visualize what the text has described: these images make the verbal code more concrete and comprehensible.

A closer look at fig. 2 reveals that the artist or compositor is more interested in representing character type, dress, and age, rather than in depicting a specific episode. The viewers can infer relationships based on the disposition of the characters within the grouping. The first two figures, the noble man and the maiden, seem to face each other in conversation. The next grouping consists of two young men and the old

${ }^{16}$ A version of this set of blocks occur in various printings of the Tragicomedia produced by the Crombergers. Griffin has zatalogued the cuts, identifying these as: Noble with robe $=W C 110 ;$ Maiden $=W C 111$; Young man with plumed hat = WC 112; Young man with hat and sword = WC 106; Old woman = WC 107. 
woman. Although this arrangement lacks the dynamic movement of a narrative woodcut, it provides the viewers with a mimetic plane in which these characters may be seen as interacting.

The disposition of the figures across the width of the page has a distinctly theatrical, staged quality. ${ }^{i 7}$ Norton has characterized the factotum blocks of this type as a kind of dramatis personae (152). The labelling of characters immediately above the cut reinforces this function. Within the visual culture of late medieval Europe, the dramatic context of these composite blocks would not escape the reader of Rojas's text. One practice in early printing was to employ composite blocks to create a theatrical context for a work. ${ }^{18}$ The first use of factotum figures is attested in an edition of Terence printed by Johann Grüninger at Strasbourg in 1496. Other European publishers quickly adopted this method to illustrate the works of Terence and Plautus. With reference to Spain, the earliest example of this manner of illustration is attributed to Stanislao Polono whose edition of Santillana's Bias contra Fortuna (Sevilla, 1502) utilizes factotum figures on the title-page. His factotum blocks came into the possession of the Crombergers whose editions of the Tragicomedia incorporated many of these same figures. Other publishers of early editions of Celestina, as Norton (152) has noted, followed the Crombergers' model with much success. Griffin points to an edition of Celestina printed by Marcio Sessa at Venice in 1531 in which Sessa employed woodcuts he had previously used in an edition of Plautus (Griffin 198-199, n. 49). The use of factotum blocks in the early decades of the sixteenth century gives Rojas's works a distinctive textual identity. Early modern readers would easily have been able to make associations between the use of these blocks and the theatricality of Rojas's text.

Each woodcut image stages the invisible aspects of the text: the dress, appearance, facial expressions of the protagonists. In a culture based on resemblances, images served as important vehicles for acquiring

17 The links with the theatrical also conform to notions prevalent in Early Modern Europe of the visual arts as "a stage on which human figures performed significant actions based on the texts of the poets" (Alpers xix). Lotman has also pointed to the connections between theater and the visual arts: "The intermediate position of the theater between the moving, continuous real world and the still, discrete world of the visual arts determined the possibility of the frequent exchanges of codes between theater and everyday behavior, on the one hand, and between theater and visual arts, on the other hand" (51).

${ }^{18}$ For a useful discussion of this topic in early modern Europe, see Moxey (8687) and Bal (303-308). 
knowledge, as Foucault notes: "It was resemblance that largely guided exegesis and the interpretation of texts; it was resemblances that organized the play of symbols, made possible knowledge of things visible and invisible, and controlled the art of representing them" (32-33). These woodcuts provide a theatrical context for the representation of Rojas's text and serve as paratextual devices which, by extension, influence both the practice of silent reading and the prelection before an audiate.

While a visual program is considered a key concepts associated with print culture (Ong 121; Jay 3; Elsky 115), it also describes a strategy which enhances the comprehension of the meaning of a given text. Since classical antiquity, theorists had recommended the use of verbal pictures ("picturae") as devices for accessing the mind's eye and ensuring the comprehension of a message. Cicero, for example, urged that visual strategies be incorporated into speeches in order to help the audience retain and understand a concept or message ("quare facillime animo teneri posse ea, quae perciperentur auribus aut cogitatione, si etiam commendatione oculorum animis traderentur...," ["things perceived by the ears or by reflection can be most easily retained in the mind if they are also conveyed to the mind through the mediation of the eyes"] $D e$ oratore 373; bk. 2, sec. 87.357). This recourse to the visual ensures the proper comprehension of ideas. Thomas Aquinas in a commentary on Aristotle notes the crucial role of images in achieving understanding: "Si non possit sine phantasmate intelligere, cum phantasma sit similitudo rei corporalis" ["In those circumstances mankind is unable to understand without images since the image is a simulacrum of a corporeal thing"] (91.312). In a similar vein, Albertus Magnus stresses the function of the visual as a tool for confirming meaning: "Auditu enim satis certus non fuit, sed visu certificabatur" ["Heard, it was not fully convincing, but seen, it would be seen to be true"] (11, lines 6-9). Within the context of print culture, visual elements such as composite blocks or narrative woodcuts perform similar functions within the mise-en-livre. The pictorial program creates paratextual links with the concepts and messages communicated by the text.

In the case of Celestina, each woodcut block foregrounds character, and at times action, so as to crystalize for the audience various messages of the text. With this pictorial code as a frame, the prelector could employ the visual register of characters and events to enrich his/her interpretation of Rojas's text. By using this repertoire as the basis for the representation of each of the protagonists, a skilled prelector could then work out the portrayal of class, age, and gender distinctions implicit in the text and offer the audiate a much more convincing aural 
experience of the text. This scenario for performing Celestina conforms with the recommendations of Proaza. Through a convincing performance of the text, the prelectores could expressively communicate to the audiate the complex emotions and situations of Rojas's work ("a mucha atención, / leyendo a Calisto mover los oyentes"). The factotum blocks and the narrative woodcuts serve as support for the aural/oral presentation of the text.

Within the context of prelection, the nature of the performance, of course, would vary from one group situation to another. Those skilled in the techniques of oral delivery would negotiate the words and images more expertly than novice prelectors. In both cases, the printed page enriches the performance of the Comedia or Tragicomedia by providing cues and visual disdascalia. It is probably not coincidental that the paratextual spaces of the early editions of Celestina encouraged a performance regime. Whereas silent reading is an acceptable means for enjoying Celestina, it disengages the reader from the social interaction implicit in an aural reception of the text. The imagined readership of Celestina, as Rojas in the Prólogo and Proaza in the octavas have characterized it, was expected to engage the text within an oralized, socialized setting. The early publishers of Celestina, attentive to these features of the text, fostered the performance aspects of Rojas's work through the visual programs analyzed above. The interrelationships of visual and verbal codes - in the early editions in particular - reinforce the representation advocated in Proaza's octavas. The result was the production of editions which simultaneously served the socioliterary demands of readers and the performance needs of prelectors. ${ }^{19}$

19 A preliminary version of this paper was presented in October 1996 at a colloquium sponsored by the Department o: Spanish, Italian, and Portuguese, The Pennsylvania State University. I wish to express my appreciation to Prof. Leon Lyday for the invitation. I owe a debt of gratitude to Frederick De Armas and Donna Rogers for their collegiality and perceptive comments. In addition, my students at Kansas were instrumental in making me see the visual dynamics of these imprints. I am especially grateful to Amy Austin, Andrea Baldomir, and Lori Willer for the critical reception of my ideas. I wish to thank Susan Rosenstein, Curator at the Hispanic Society of America, New York, for her assistance in obtaining materials for this study. Cynthia L. Barnett kindly read portions of this paper and saved me from numerous mistakes. For errors which remain, I alone am responsible. 


\section{Works Cited}

Albertus Magnus. Postilla super Isaiam. Ed. Ferdinand Siepmann. Aschendorff: Monasterii Westfalorum, 1952. Vol. 19 of Opera omnia. 37 vols. Aschendorff: Monasterii Westfalorum, 1900-1978.

Alpers, Svetlana. The Art of Describing: Dutch Art in the Seventeenth Century. Chicago: U Chicago P, 1988.

Bal, Mieke. "On Looking and Reading: Word and Image, Visual Poetics, and Comparative Arts." Semiotica 76 (1989): 283-320.

Berndt Kelley, Erna Ruth. "Mute Commentaries on a Text: The Illustrations of the Comedia de Calisto y Melibea." In Fernando de Rojas and Celestina: Approaching the Fifth Centenary. Eds. Ivy Corfis and Joseph T. Snow. Madison: Hispanic Seminary of Medieval Studies, 1993. 193-227.

Camille, Michael. "Reading the Printed Image: Illuminations and Woodcuts of the Pelerinage de la vie humaine in the Fifteenth Century." In Printing the Word: The Social History of Books circa 1450-1520. Ed. Sandra L. Hindman. Ithaca: Cornell UP, 1991. 259290.

Chartier, Roger. "Texts, Printing, Readings." In The New Cultural History. Ed. Lynn Hunt. Berkeley: U California P, 1989. 154-175.

. "Introduction." In The Culture of Print: Power and the Use of Print in Early Modern Europe. Princeton: Princeton UP, 1989. 1-9.

. "Leisure and Sociability: Reading Aloud in Early Modern Europe."

In Urban Life in the Renaissance. Ed. Susan Zimmerman and Ronald F. E. Weissman. Newark, Delaware: U Delaware P, 1989. 103-120.

The Order of Books: Readers, Authors, and Libraries in Europe between the Fourteenth and Eighteenth Centuries. Stanford: Stanford UP, 1994.

Cicero, Marcus Tullius. De oratore. Ed. O. Harnecker. 3 vols. Amsterdam: Hakkert, 1965.

Coleman, Joyce. Public Reading and the Reading Public in Late Medieval England and France. Cambridge: Cambridge UP, 1996.

Corfis, Ivy. "Celestina as Drama: Commentary by a 16th-Century Reader." Romance Philology 47 (1993-1994): 33-47.

Davis, Paul. The Lives and Times of Ebenezer Scrooge. New Haven: Yale UP, 1990.

Davis, Whitney. Masking the Blow: The Scene of Representation in Late Prehistoric Egyptian Art. Berkeley: U California P, 1992.

Elsky, Martin. Authorizing Words: Speech, Writing, and Print in the English Renaissance. Ithaca: Cornell UP, 1989.

Foucault, Michel. The Order of Things: An Archaeology of the Human Sciences. New York: Vintage Books, 1973. 
Gilman, Stephen. The Art of 'La Celestina'. Madison: U Wisconsin P, 1956. Goldschmidt, Ernest. Medieval Texts and their First Appearance in Print. London: Bibliographical Society, 1943.

Griffin, Clive. The Crombergers of Seville. The History of a Printing and Merchant Dynasty. Oxford: Claiendon, 1988.

Hirsch, Rudolf. Printing, Selling and Reading, 1450-1550. Wiesbaden: Otto Harrassowitz, 1967.

Holland, Norman. "Unity Identity Text Self." In Reader-Response: From Formalism to Post Structuralism. Ed. Jane P. Tompkins. Baltimore: The Johns Hopkins UP, 1980. 118-133.

Jay, Martin. "Scopic Regimes of Modernity." In Vision and Visuality. Ed. Hal Foster. Dia Art Foundation Discussions in Contemporary Culture, 2. Seattle: Bay Press, 1988. 3-23.

Jones, Joseph R. "Isidore and the Theater." Comparative Drama 16 (1982): 26-48.

Lacarra, María Eugenia. Cómo leer 'La Celestina'. Madrid: Júcar, 1990.

Lawrance, J. N. H. "On the Title Tragicomedia de Calisto y Melibea." In Letters and Society in Fifteenth-Century Spain. Studies Presented to P. E. Russell on his Eightieth Birthday. Ed. Alan Deyermond and Jeremy Lawrance. Llangrannog: Dolphin, 1993. 79-92.

Lida de Malkiel, María Rosa. La originalidad artística de 'La Celestina'. Buenos Aires: EUDEBA, 1962.

Lotman, Yury. "Painting and the Language of Theater: Notes on the Problem of Iconic Rhetoric." In Tekstura: Russian Essays on Visual Culture. Eds. Alla Efimova and Lev Manovich. Chicago: Chicago UP, 1993. 45-55.

McPheeters, D. W. El humanista espaniol Alonso de Proaza. Valencia: Castalia, 1961.

Marciales, Miguel, ed. Celestina. Tragicomedia de Calisto y Melibea. By Fernando de Rojas. Eds. Brian Dutton and Joseph T. Snow. Illinois Medieval Monographs, 1. 2 Vols. Urbana: U Illinois P, 1985.

Maurizi, Françoise. "'Dize el modo que se ha de tener leyendo esta (tragi)comedia': breve aproximación al paratexto de La Celestina." Bulletin of Hispanic Studies (Liverpool) 74 (1997): 151157.

Miguel Martínez, Emilio de. 'La Celestina' de Rojas. Madrid: Gredos, 1996. Moxey, Keith. The Practice of Theory: Poststructuralism, Cultural Politics, and Art History. Ithaca: Cornell UP, 1994.

Noakes, Susan. Timely Reading: Between Exegesis and Interpretation. Ithaca: Cornell UP, 1988.

Norton, F. J. Printing in Spain: 1501-1;20. Cambridge: Cambridge UP, 1966. 
Ong, Walter. Orality and Literacy: The Technologizing of the Word. New York: Routledge, 1982.

Rivera, Isidro J. "Visual Structures and Verbal Representation in the Comedia de Calisto y Melibea (Burgos, 1499?)." Celestinesca 19 (1995): 3-30.

Rojas, Fernando de. Tragicomedia de Calisto y Melibea. [Salamanca 1502]. Rome: Antonio de Blado [for Antonio de Salamanca], c. 1520.

- Tragicomedia de Calisto y Melibea. Sevilla? [Venice]: [Juan Batista Pedrezano], 1523.

Russell, Peter E. "Introducción." In La Celestina: Comedia o Tragicomedia de Calisto y Melibea. Madrid: Castalia, 1991. 11-158.

Snow, Joseph T. "The Iconography of Early Celestinas. I: The First French Translation (1527)." Celestinesca 8.2 (1984): 25-39.

. "La iconografía de tres Celestinas tempranas (Burgos, 1499; Sevilla, 1518; Valencia, 1514): unas observaciones." Dicenda: Cuadernos de filología hispánica 6 (1987): 255-277.

Stern, Charlotte. The Medieval Theater in Castile. Medieval \& Renaissance Texts \& Studies, 156. Binghamton, New York: Center for Medieval and Early Renaissance Studies, 1996.

Tedeschi, Martha. "Publish and Perish: The Career of Lienhart Holle in Ulm." In Printing the Word: The Social History of Books circa 14501520. Ed. Sandra L. Hindman. Ithaca: Cornell UP, 1991. 41-67.

Thomas Aquinas. In Aristotelis libros de sensu et sensato, de memoria et reminiscentia commentarium. Ed. R. M. Spiazzi. Turin: Marietti, ' 1949.

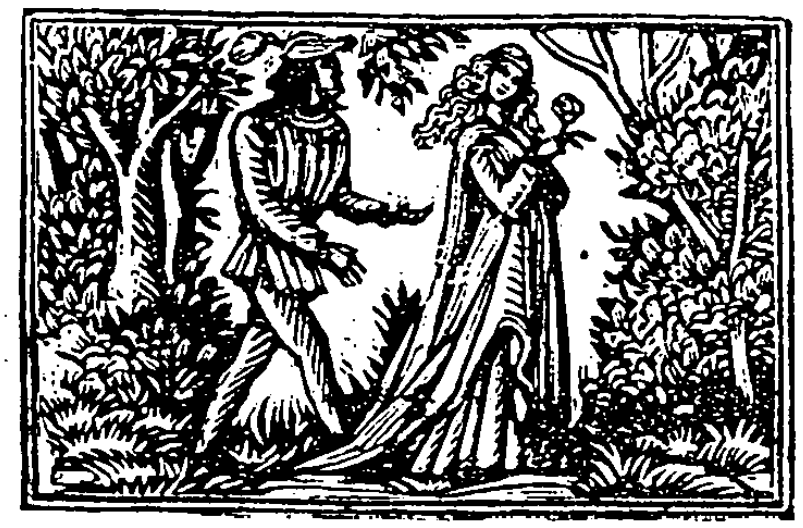

Acto I. De la traducción rusa (1959). 